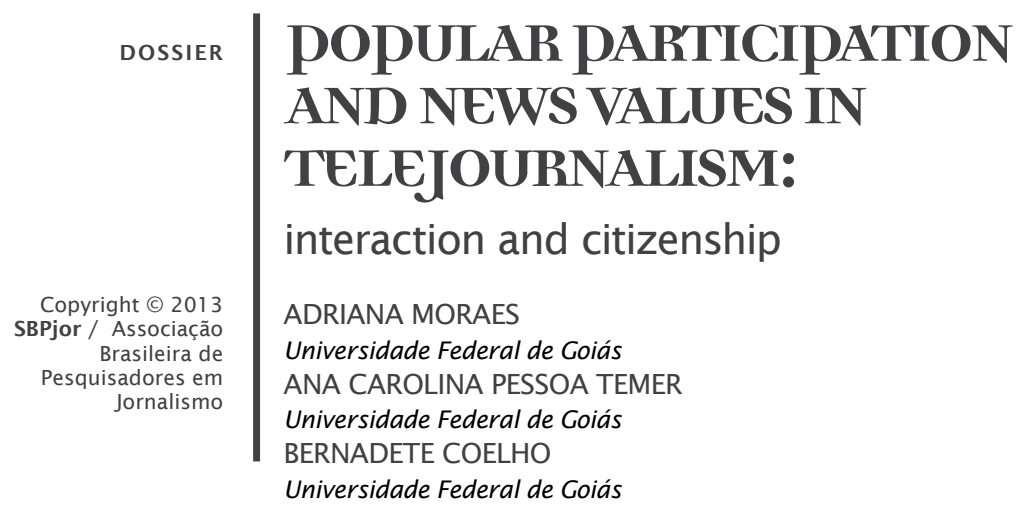

\begin{abstract}
This article consists of a reflection on the citizenship regarding means of communication, more specifically television. It is based on the principle that the viewer's participation in television news program content should be configured as a right and, therefore, a citizenship guarantee. The study shows how journalists can be involved in the practice of citizenship, basing on the newsworthiness criteria that shape these professionals' routines in the production process of news that is conveyed in telejournalism. The object of this research is the news frame "Quero ver na TV" "I want to see on TV"), created by Anhanguera Television, affiliated with Rede Globo, to be an interactivity channel among viewers and journalists.
\end{abstract}

Keywords: Citizenship. Interactivity. Telejournalism.

\title{
PARTICIPAÇÃO POPULAR E OS VALORES-NOTÍCIA NO TELEJORNALISMO: interação e cidadania
}

RESUMO - Este trabalho consiste numa reflexão sobre a cidadania nos meios de comunicação, mais especificamente na televisão. Está fundamentado no princípio de que a participação do telespectador no conteúdo do telejornal deve configurar-se como um direito e, portanto, uma garantia de cidadania. O trabalho expõe como os jornalistas podem interferir na prática da cidadania a partir dos critérios de noticiabilidade que moldam a rotina desses profissionais no processo de produção da notícia veiculada no telejornalismo. O objeto da pesquisa é o quadro "Quero Ver na TV", criado pela Televisão Anhanguera, afiliada da Rede Globo, para ser um canal de interatividade entre os telespectadores e os jornalistas.

Palavras-chave: Cidadania. Interatividade. Telejornalismo.

\section{LA PARTICIPACIÓN POPULAR Y LOS VALORES-NOTICIA EN EL TELEPERIODISMO: interacción y ciudadanía}

RESUMEN - Este trabajo consiste en una reflexión sobre la ciudadanía en los medios de comunicación, más específicamente en la televisión. Se fundamenta en el principio de que la participación del telespectador en el contenido de los telediarios debe configurarse como un derecho y, por tanto, una garantía de ciudadanía. El trabajo expone la forma en que los periodistas pueden interferir en el ejercicio de la ciudadanía, a partir de los criterios de noticiabilidad que moldean la rutina de estos profesionales en el proceso de producción de la noticia vehiculada por el teleperiodismo. El objeto de la investigación es el espacio "Quiero Ver en la TV", creado por la Televisión Anhanguera, filial de la Red Globo, para ser un canal de interactividad entre los telespectadores y los periodistas.

Palabras clave: Ciudadanía. Interactividad. Teleperiodismo. 


\section{INTRODUCTION}

The majority of Brazilians are still basically informed by what is shown on television. With this perspective in mind, telejournalism becomes an important part in this process, since it is news made on television and for television and therefore, it plays two roles: entertaining as television and informing as journalism.

This generally means that telejournalism has well-defined characteristics: easy language, the use of images to show the news, dealing with issues that interest a general and diverse audience, which are presented through a kind of script or dramatization, enabling the viewer's understanding. It is via the TV news program that the citizen becomes aware of what is happening in the neighborhood, city, country and world. According to Vizeu (2005), "telejournalism can be considered a 'place' by Brazilians, very similar to family, friends, school, religion and consumption. We watch television and see the world and it sees us."

Despite the supremacy that free-to-air (FTA) television still maintains ${ }^{2}$ in terms of news reach, it has been threatened by the advent and spread of new communication technologies. Internet, cell phones, digital TV or digital portable machines have revolutionized access to information and brought citizens closer to the news, also allowing them to interfere in content, as in the case of the internet.

Consequently, easy access to information has directly influenced the behavior of individuals and enabled the development of a new paradigm in communication as it presents an interactive potential. Thus, the receptor is now more avid for current and instant information and wants to be an active participant in information dissemination.

Observing this behavioral change and fearing the preference for new technologies, television stations seek the receptor, increasingly stimulating their participation in media content to guarantee audience viewing. Therefore, we should also see this participation as social change, since the relationship between the citizen and the media is part of a historical process of the citizen's rights and, consequently, of citizenship.

Telejournalism seeks this new path because it has always been a means the citizen could not interfere in as it regards production process, such as the choice of themes and subjects that become news, suggestions, and opinions. Although the change is still small, telejournalism is continuously increasing the use of instruments that allow viewer participation in daily editions. Videos, photos, internet 
testimonies or suggestions of news reports sent by the audience are well-regarded by journalists in the newsroom.

But to which extent can this "participative audience"3 really be a decisive aspect in selection, production, construction and exhibition of the news in telejournalism? The research presented in this work seeks to identify how this interaction develops itself when journalists of an FTA television newsroom have productive routines and newsworthiness criteria to decide what news is "worth" being reported. To which extent can these criteria be a barrier to viewer participation in news casting and, therefore, a barrier to effective citizenship, when they see themselves inserted into a society where they participate in information and have the freedom to manifest and express what they think? May the viewer's wishes overcome the news that continuously appear in newsrooms?

The research has identified how newsworthiness criteria and production routines can influence selection of the viewer's original piece of news. We have analyzed the suggestions and news requests that were written for the news frame "Quero ver na TV" from Anhanguera Television, a Rede Globo branch in Goiás and compared them to the criteria used by journalists to select those considered the most appropriate.

The influence that the journalist has in determining what is news is approached by many authors in the field of communication through gatekeeper and newsmaking studies and organizational theory, which talk about message selection and production process. To choose an agenda, journalists consider, for example, elements like time, novelty, currency and dramatization, as can be found in Traquina (2008) and Charaudeau (2006)'s approach.

It is true that these suggestions are sent through various means, such as letters, telephone, personal or corporative e-mails and the television's webpage ${ }^{4}$. However, we have opted for analyzing only the messages sent to the news frame "Quero ver na TV", or QVT', since it is a communication channel created by the television station for the viewer to send suggestions of topics that may become news reports broadcasted in one of the three TV news programs. Therefore, the choice was based on the fact that QVT is considered by television journalists to be a new and indispensable communication and approach channel of interaction with the viewer.

In this article, communication is defined by Martino (2001) as an intentional relation exerted on another person. Television can be considered a media means of communication; the relation with the viewer, although it could also be defined as an almost mediated 
interaction (THOMPSON, 1995).

These concepts allow us to discuss the mediating role of television and telejournalism in society. In addition, the concept of citizenship is defined from a viewpoint that takes into consideration the participation of individuals in information production as a right (GENTILLI, 2005) and a feeling of belonging, as brought by Cortina (2005). Further, we adopt the concept of active citizenship through political participation in democracy as discussed by Benevides (2003). Viewer participation will also be talked about, basing on the concept of interaction proposed by José Luiz Braga (2005).

Television becomes distant to the viewer when this relation is unidirectional, without any exchange between sender and receptor. However, technological changes, which allow access to more immediate and mobile information, and behavioral changes of viewers, who experiment with the possibility of being news senders, also cause a change in journalism and telejournalism: the need to have the audience as a source, contributing effectively to the production of information.

Vizeu and Siqueira (2010) have named this participation "participative audience" and it was already named by Chaparro (2009) revolution sources. Among the possibilities for viewer participation created by television stations, such as the news frame "Quero ver na TV", one can enhance the possibility of "active citizenship" brought by Benevides (2003) when the citizen becomes aware of the possibility of levying and having more political participation in the society in which they live.

\section{ANHANGUERA TELEVISION NEWS PROGRAMS, THE SEARCH FOR AUDIENCE AND THE GLOBAL MODEL}

In 2010, Anhanguera TV remodeled the sets of its TV news programs, adopting an editorial line similar to that of RJTV, a Rede Globo local TV news program from Rio de Janeiro, which also underwent remodeling in order to "change the simple news presentation to a conversation with the viewer". The proposition of the new TV sets was to make the program faster and more informal.

Journalists, however, were called upon to review the journalism model under development at that time. The current rule is always to use popular and clear language, to have issues that are relevant to the target audience of each program, especially a poorer audience (the "C class"), with shorter, lighter, more informal and more objective news reports so 
that the viewer continues to pay attention, as well as using short editions and graphics.

In Goiás, the decrease of audience numbers even brought about the replacement of the chief director of telejournalism by another professional from Rede Record São Paulo. He was responsible for a series of changes, mainly in the content of the network's TV news programs, with a view to promoting greater identification with the viewer and facing competing broadcasters. The TV news program that underwent the most significant reformulation was the First Edition of Jornal Anhaguera (Anhanguera News). Among the network's TV news programs, it was the one with the biggest drop in audience numbers and, consequently, a task force had to be created to compete for viewers with SBT's Jornal do Meio Dia and Balanço Geral from Rede Record, which resulted in the arrival of other foreign professionals to work in presentation and news casting and in Jornal do Campo (country news casting).

Among the changes, the most impactful was the one which introduced shorter texts and reporter participation, with shorter and more creative stories of service and human interest. The intention was to amaze viewers, especially with more creative news announcing. To this end, journalists had to basically employ advertising techniques.

Another change concerned the relationship with state government. TV, which has always been associated with state government, untied its bonds with it, even with the financial dependence of public government announcements, as happens with most FTA and commercial TVs. This initiative was relatively small but significant in reformulating the editorial line of the network's journalism. Furthermore, as part of the process of becoming a popular television station, the news frame "Quero ver na TV" was created as an alternative, with the objective of being the communication channel with the audience and promoting interactivity, following a trend in means of communication.

\section{QUERO VER NA TV}

The project "Quero ver na TV" was created in 2008, for viewers to have a channel specifically for sending suggestions of news reports that they would like to see on the television station's news programs. The name of the news frame was chosen by the newsroom professionals themselves and the idea was that this name would convey the goal of the project: to allow viewers to identify with the content broadcasted by Anhanguera television. To send a suggestion, viewers need only access 
the website of the television station (www.gl.com.br) and fill in a form.

When they access the webpage, a window pops up, asking the viewer to leave their name, contact, e-mail address and news suggestion, which will be sent by internet to the registered journalists. These include: executive editors, news casting chiefs and editors-in-chief of the program. The journalists then select the topics and forward them to the producers who, with an agenda, enable the making of the news casting. The choice of TV news program and the day on which the suggested piece of news will be broadcasted are determined by the news casting chiefs and editors-in-chief.

A brief analysis of "Quero ver na TV" shows that there are fifteen to twenty suggestions from viewers every day. Most of them identify themselves with their name, address and telephone number. The stories sent by the audience are varied but most of them refer to city problems such as asphalt, public lighting, public security, traffic, transportation and health. It is what Cortina (2005) conceptualizes as social citizenship, where rights are guaranteed by the country.

In order to do the research, we looked into a selection of suggestions sent to the news frame with each of the editor-in-chiefs of the three TV news programs that air daily: Bom Dia Goiás ("Good Morning Goiás"), Jornal Anhanguera $1^{a}$ Edição ("Jornal Anhaguera (Anhanguera

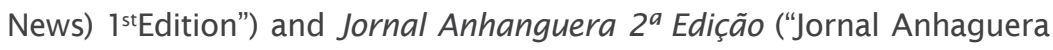
(Anhanguera News) $2^{\text {nd }}$ Edition"). We also observed which were selected and which effectively became the news and were broadcasted. Our analysis was carried out based on the criteria of newsworthiness and the news values that permeate the work of television journalists, basing on the perspectives of Nelson Traquina and Patrik Charaudeau.

In general, selected suggestions are forwarded to the TV news production team to be made feasible. Mostly, producers contact the viewer who made the suggestion in order to check the story and schedule the shooting. The viewer is invited to participate or not in the news. After filming, the reporter passes the material on to the editing team. The resulting news from "Quero ver na TV" does not have a special format that distinguishes them from the others. Identification can only occur during the TV news program and it is the editor-in-chief who mentions or not the author of the suggestion.

This practice is best perceived in Jornal Anhaguera (Anhanguera News) $1^{\text {st }}$ Edition, which is currently seeking closeness with the audience. In this case, a logo of the news frame is shown on the screen while the presenter announces the news. The name of the viewer who sent the 
suggestion is mentioned (or not) by the presenter after the news is aired.

\section{NEWS VALUE AND THE NEWSROOM JOURNALISTS}

The analysis was carried out under the clipping of news values of selection, because the intention was to verify if and how the journalists criteria have influenced the selection of suggestions of news sent by viewers. Therefore, we shall not further the study of construction news values but rather only cite them, because they determine criteria within the elaboration or construction of news, which, regarding television, is TV news.

According to Traquina (2008), the construction news value can be summed up in a word: simplification. Thus, the simpler and less ambiguous the news is, the easier it can be assimilated and understood. Consequently, journalists are obliged to write in a way that makes the situation easy to understand. Overall, the news value is what can be termed an act or intervening exaggeration, or consequences of the act for it to be noted.

It is understood that it is the responsibility of journalists to ensure the story is relevant and meaningful to others. Regarding personalization, the logic is to value the people involved in the story because people are interested in others and can identify with the problem, which draws attention to the news. Finally, we address the news value of dramatization, which is always marked, especially in prints and television. It is the reinforcement of the most critical aspect, emotional or conflictual, through melodramatic reports.

Among the news values criteria, it is worth highlighting the arguments brought by Charaudeau (2006). The fact that many events are not covered by the media is related to the need to make the news topical. The author explains that, to the media, "what is happening right now" is what counts as news. Therefore, the smaller the amount of time between the event, news production, broadcasting and consumption on behalf of the the receptor, the more value it has.

Charaudeau (2006) also defines the existence of a media contemporaneity. "The fact is that the happening of the event is the most consubstantial as possible to the act of the news broadcasting and its consumption. Hence, it is preferable to refer to contemporality instead of contemporaneity." In the media, an event is constantly replaced by another when the first loses current value. There is an urgent demand for new facts so as to avoid informational emptiness. The present is 
then constructed, with a succession of news highlighted by journalists. Ubiquity and proximity are also considered newsworthiness criteria.

When news is distant, the media uses several resources to reach it, such as: correspondents, news agencies, official and unofficial sources. Charaudeau (2006) says that this leads to an illusion of the viewer's ubiquity, whereby they feel close to what is happening in many parts of the world at the same time. In addition to that, spatial proximity gives quality to a private matter, which the media considers to be more interesting to the citizen because the event is near the receiving end in the same physical space. Accordingly, it is the way news is treated that makes the event near or distant. A story can be broadcasted nationally but a local TV station can use the theme so that it reverberates locally.

Two other important criteria in the hierarchy of events are explored by Charaudeau. External criteria is defined by facing the way the event appeared. They can be represented by factuality with unexpected features, when they cannot be foreseen; programmed, when there is a calendar that organizes social life; and they can be created, when they are provoked by an institutional and/or political sector.

Finally, internal criteria are the choices made by the media itself to build representations that may interest or thrill the audience, such as: the unusual, mystery, coincidence, tragedy, horror, disorder and triumph.

Our research is underpinned by the gatekeeper and newsmaking theories, which situate journalists' work in the TV news program newsroom, from news selection to broadcasting. Therefore, suggestions of the news frame "Quero ver na TV" need to be approved of by a selector, editor-in-chief or the news chief, who fulfills the role of gatekeeper. They receive all the news suggestions sent by the audience. Before forwarding them to the production team, news chiefs select the stories that are likely to become news.

Selection is influenced by news values, as demonstrated by the newsmaking theory. News values are recognized as a newsworthiness component present throughout the journalistic process. Journalists base on them, even if unconsciously, to transform daily facts into news for the citizen.

In the news frame "Quero ver na TV", these values are also crucial for the editors' decisions. During selection, we realized that the suggestions dismissed by the editor of a certain TV news program are not forwarded to the editor of another and therefore lost in the selection process. For instance, the suggestions classified as regarding 
neighborhood, asphalt, holes in the street and school transportation were assessed by the editor of Jornal Anhaguera (Anhanguera News) $2^{\text {nd }}$ Edition and dismissed, without being forwarded to another news program.

Furthermore, the news frame "Quero ver na TV" has high levels of participation from viewers from smaller cities, outside the metropolitan area of Goiania. The suggestions come mainly from cities where there is an affiliated TV network ${ }^{6}$ of Anhanguera Television in Goiás. Just like in the capital city, viewers from the countryside use "Quero ver na TV" to suggest the propagation of topics that are part of the local reality, such as neighborhood, traffic and health.

We found that the suggestions sent by these viewers were usually rejected by editors of TV news produced in Goiania. Again, the audience is the selection criteria. Therefore, the e-mails sent by people from Jataí, Rio Verde, Santa Helena, Anápolis, Niquelândia and Palmeiras were not forwarded. The main explanation is that audience research of the three TV news programs is carried out in Goiania only.

While the journalists' news values reject suggestions from viewers on the daily news, these values are also decisive in assuring that other suggestions are accepted and the event is noticed. The topic areas that were used by the journalists can be summarized in: environment, public safety, traffic, health, education, transportation and others (such as the elderly).

\section{ANALYZING “QUERO VER NA TV”}

The analysis of the suggestions was determined as follows: each of the three editors-in-chief of the TV news programs selected the suggestions sent over two days. Since there is no limit to the number of suggestions that can be sent by e-mail to "Quero ver na TV", all the suggestions sent in this period were analyzed. For Good Morning Goias, the editor-in-chief received 12 e-mails from viewers; to Jornal Anhaguera (Anhanguera News) $1^{\text {st }}$ Edition, 32 suggestions were analyzed; and to Jornal Anhaguera (Anhanguera News) $2^{\text {nd }}$ Edition, there were 22 suggestions, totaling 66 requests to news reports from viewers.

The 66 suggestions were classified by topic, alike the relation made by Temer (2002): environment, education, traffic, neighborhood, police/public safety, denouncements, health, politics, public transportation, culture, economics, city, roads, leisure, amongst others (tourism, curiosity, religion). 
Of the 66 suggestions sent, 28 were selected by the editors-inchief. However, only 19 were used in one of the TV news programs as news reports, viewer's opinions or participation with photos, while were selected but not used. Of the 66 , the journalists refused 38 at the time of the selection.

We also analyzed the suggestions that were sent but not used. Refused subject matters included: environment, city, culture, education, denouncements, traffic, neighborhood, politics, public safety, economics, public transportation, health, amongst others (criminal responsability, religion, complaint, drugs, daycare, roads, comments, honoring, and celebrity).

\section{REFUSED SUGGESTIONS AND THE NEWS VALUES AS THE JOURNALISTS' ARGUMENTS}

The submission of the public's stories to journalists' selecting power can be identified in the way suggestions are selected. Although they said in the interview that "Quero ver na TV" is important and that they value interaction with the receptor, the journalists do not follow a daily selection routine. During our observation of interviews, we found that on days when there are many factual news stories (that happen on that day and must be aired), journalists are busier with the newsroom routine and airing the TV news program, the latest or hottest news and, therefore, disregard viewer participation.

In fact, in carrying out research, we found that viewers' suggestions were not even analyzed for several days, as e-mails sent were not read, even if nothing exceptional had happened in the newsroom. The suggestions that were read and refused by selectors, were subordinated to newsworthiness criteria of productive routine and journalistic organization, as talked about by Traquina (2008).

In all cases it is also clear from the interviewees that the journalistic community alone has the power to know, and determines what interests viewers, or what information they want to obtain, or not. It is important to state that the criteria do not eliminate one another and can be complementary.

Regarding education, the suggestions that were refused represented complaints from city dwellers of Luziânia and Aparecida de Goiânia over the delayed period of time for completing the Teaching Course for Young People and Adults, and the conditions at a state school. In both cases, viewers presented complaints about subjects of daily 
interest to them but which also affected other citizens. The argument of the editor-in-chief of Good Morning Goias was that the complaint was "a very particular problem, even though, according to some data from the State Board of Education, around 80 thousand students are enrolled in the Teaching Course for Young People and Adults".

In the case of the editor of Jornal Anhaguera (Anhanguera News) $1^{\text {st }}$ Edition, although the complaints about the state school's conditions form the program's profile, the problem was small, since Physical Education classes were not interrupted and are not very important for the school curriculum. The data revealed a contradiction on behalf of the editor because the TV station values sport as a way of removing underprivileged children from the streets and a means of social mobility.

Regarding the newsworthiness and relevance criteria (TRAQUINA, 2008), 30 aspects were observed, despite mistakes in interpretation of data in those cases, since the journalists considered that the news only has value for those currently experiencing the situations. The aforementioned example of the school, for instance, does not involve a great amount of students, or has a significant impact on peoples' lives, since Physical Education classes were not canceled and the theoretical content was considered more important. These elements, which are essential for the subject to be noticed, are constantly quoted by the journalists at the moment of the selection.

The lack of notability and/or lack of relevance, however, are still noticeable in the refusal of suggestions that involve self-reflection or the receptor's private interest. The e-mails which were evaluated and refused based on those criteria concerned: a hospital employee complaining about traffic tickets for parking in non-permitted places near her work; a city dweller requesting the shutdown of a garage working in front of her house, due to noise; a religious party held on a farm in the countryside; a city dweller who had not received the deed to his house. The journalist even considers it to be "an evaluation mistake by the viewer" and "a private view", stating that "it does not interest anyone".

We found that the personal interpretation of journalists leads, even if unconsciously, to the refusal of suggestions and ultimately eliminates the mediating function of journalism. Viewers' proposals could be the basis for discussions on the TV news program about the problems that interest not only a single person, but also the community as a whole.

The suggestion about tickets could start a debate over the socalled ticket industry, for example. The viewer who complained about a 
garage in front of her house could exemplify news reports about urban zoning and the master plan for cities with over one million people. The religious party in the countryside would aid coverage on the culture and traditions of people from Goiás, while the example of the city dweller who did not get the deed to his house could represent stories about service, informing consumers about the precautions when buying real estate.

\section{SUGGESTIONS USED AND NEWS VALUES AS JOURNALISTS' ARGUMENTS}

The topics used by journalists included the following: environment, public safety, traffic, health, education, transportation, amongst others (such as the elderly). From this perspective, viewer's participation, as motivated by "Quero ver na TV", could always be used when what needs to be shown on TV makes the journalist job easier to being done. For example, a suggestion sent by a viewer about the conservation of a park was used in one of the programs, in accordance with the availability criteria. The picture sent by e-mail was shown in Bom Dia Goiás (Good Morning Goias) on the news frame "You Are The Reporter", which proposes interactivity. Because the picture was sent, there was no need to use a team of a cameraman and reporter to report on the matter, and this, according to the editor, "maybe would not have been done due to more important issues that day". Also, this type of participation is always reinforced on the news and valued by journalists.

The news is the recording of real events framed within a journalistic narrative. However, it is programs that have to assume a workload on air defined by programming, which is generally controlled by the TV station. Thus, journalists do not have the freedom to decide on more or less news for the program because they are obliged to use up pre-determined time. In the routine of newsroom professionals, this is one of the most worrying factors for editors and, therefore, it influences daily editing planning. If the TV news program is small, there needs to be enough news to complete it; if it is large, it will be necessary to choose the news which is more interesting and dismiss other parts.

When it comes to the logic of time and duration of the TV news program and of what happens in the city, many events may (or not) become news. In most cases, weekdays (Monday through Friday) comprise more news, since commerce, schools, banks and public agencies are working, people are working and more tuned in to daily 
events. On holidays and weekends, however, newsworthy facts are not provided, unless something extraordinary happens, such as a crime, scandal or an accident.

Based on this perspective, the newsworthy day was news value that defined the use of a suggestion about parking spaces for the elderly. The matter was also chosen as a potential topic of interest to many people and for the "lack of power control from the state", characterizing the infraction and rules violation news value. Still, the news report was only broadcasted on the Saturday TV news program, a day of few stories and a larger time frame for the news program. In fact, according to the editor, the matter was broadcasted because "we had to use the story on the elderly in order to fill a gap in the program."

The acceptance by journalists of a viewer's request for explanations of traffic during the "Exposição Agropecuária" (Agricultural Exposition) was on account of its topicality and relevance. The exposition attracts thousands of visitors and traffic, which is diverted, becomes hectic in areas around the venue, causing many to complain and many news reports. The suggestion was chosen because "it interests a much broader audience" and was broadcasted on different TV news programs and different days (enclosed). On one occasion the news was aired, the program was also covering another traffic problem - the inauguration of an avenue that had been interdicted several months before and caused much controversy amongst drivers and the press.

Visibility and tangibility are essential conditions for television news, as mentioned above, for the purposes of social reach. In two of the accepted and used suggestions, journalists were concerned about guaranteeing "good images and good on the spot events". Observing these criteria, a news report on sidewalks invaded by bars and restaurants and another on delays and overcrowding in public transport, were broadcasted.

We also discovered that, in addition to the matter of selection of subject/agenda suggested by viewers, it is important to observe how and when suggestions are broadcasted. For instance, the sidewalk story was chosen and produced in June, but only aired two months later, on August $3^{\text {rd }}$. On this edition of the TV news program, the subject of sidewalks was linked to the launch of a guide to sustainable sidewalks, attributing topicality to the matter. It is evident that, despite approval, topics suggested by viewers must also meet other interests or opportunities that journalists include to address a topic. In the case of the sidewalk suggestion, the focus was to approach the matter from a standpoint that 
considered right and wrong, there being, the viewer's opinion describing the problem and the guide, the solution.

Significantly, whilst research was being made, one story had a great impact on local news content: the discovering of fraud in the "vestibular" for the Medicine course in the Catholic University of Goias (PUC-GO). The accused were identified on the news and the university changed the date of the new exam, which provoked a strong reaction from candidates because it was on the same day as other "vestibular" tests. Thus, the ordeal created eight stories on the three TV news programs studied in this article. This number was justified because the fraud was, according to journalists, a newsworthy event in itself, since it aroused the interest of many people and met the news values of relevance, surprise, infraction and scandal.

The matter attracted viewers' attention and they sent 11 complaints or suggestions oh directly or indirectly related stories. Amongst them, there were complaints from numerous students about the new date of the tests. Candidates who manifested themselves by e-mail asked for the date to be changed. The argument was that it would coincide with exams of other universities.

The subject was discussed for two days on the three programs (attachment), mainly on Jornal Anhaguera (Anhanguera News) $1^{\text {st }}$ Edition because it was considered appropriate for the viewers' profiles. The news program talked about the matter for two days, on June $5^{\text {th }}$, a day after the fraud was discovered. A 2-minute-34-second news report was broadcasted about the investigation on the case and the effects on students. Soon after, the TV presenter read a note comparing the answers of the fraudsters with the official answer key, aiming to know if the fraudsters would have passed the test.

Repercussions of the topic on viewers motivated new coverage, since many e-mails had been sent to "Quero ver na TV". On June $6^{\text {th }}$, the program again talked about the topic and, due to the interest of students, gave more time to the problem. The subject was valued in many ways in the editing room. In the first part, a note coverage reminding viewers of the case was aired, following an outline of the intense competition for Medicine, the number of vacancies and candidates. Also in the first part, e-mails from candidates were read in the studio, forming the basis of the live interview with the University spokesperson, who determined the new date for the exam. Hence, the fraud can be regarded as having time news value, "when a topic acquires newsworthiness and remains a topic with news value for a longer period of time." (TRAQUINA, 2008, p. 82). 
By bringing together these two news values - visuality and conflict - the suggestion about dangers faced by motorcyclists on streets was accepted and broadcasted for two days in Jornal Anhaguera (Anhanguera News) $1^{\text {st }}$ Edition. On May $28^{\text {th }}$, a news report about the risks caused by motorcycles was broadcasted in the first part of the program (attached); a live interview was conducted soon after and an internet poll about the worst infractions of motorcyclists motivated the audience to participate. The poll was referred to frequently in that Edition because it created an expectation over the final result. The viewers/internet users who voted on the alternatives presented by the news program tuned in to know the end result. Therefore, in all parts, the matter was approached using news reports, live interviews and partial results of voting.

Television journalism is typified by the search for topics that could have an impact in the community and reinforce the TV news program's identification with the citizen.

\section{CONSIDERATIONS}

Our study tried to analyze how the journalists' criteria can influence the participation of viewers in TV news program content. Thereafter, we observed that the relation between receptor and sender can be set up as a citizenship process.

When individuals look for ways to express their ideas, give their opinions or claim rights, they are playing the role of active citizens, who participate in the decisions that concern them or their community. This relation does not annul other aspects of citizenship, but stands out from the others as an action, not a reaction to the actions of the state or any other social sector. It is also important to highlight that not every viewer's participation corresponds to an individual action, given that many of them correspond to answers or indirect instigations from the TV news program production.

Taken to an extreme, the news frame "QueroVer na TV" is a proposal from the telejournalism of TV stations which is clearly focused on a strategy to maintain/broaden the audience, not a construction or demand from the receiving audience and, therefore, does not respond strictu senso to a demand of the population, or part of the population, and does not fit with the idea of active citizenship. The resource is used, however, considering that the community is not obliged to manifest itself, or present many suggestions.

The study also found that viewers feel like active citizens when 
they see that they can be a kind of information producer, when the subject they suggest becomes news on a TV news program. Furthermore, in many cases, viewers whose suggestions were broadcasted returned to make a comment or even express gratitude. It is also clear that when suggestions from viewers become news reports, the number of e-mails increases. It appears that participating in the content is, for citizens, an appreciation of their ideas.

Interviews with the editors-in-chief of the TV news programs demonstrated repeatedly that journalists are conditioned by the format of the means of communication and news program they work for. Moreover, they are conditioned according to the interpretation (usually hasty, without further discussion or analysis) of these editors/selectors, rather than the "people's interest". Accordingly, the observations made in the development of the research point to a doubly serious situation: the inefficiency of the country, denounced by the viewers themselves, is reinforced by the little importance or the automatized and superficial way telejournalism teams treat this popular participation.

The minor importance attached to popular participation is clear. Although a daily, productive routine to air the news is kept, there are no routines for evaluating e-mails sent by viewers. Consequently, no defined rules for selection and agenda production work are suggested in "Quero ver na TV".

During the period in which research was made, this choice was the responsibility of editors-in-chief and news chiefs who, nonetheless, did not receive specific guidance for the choice of suggestions, apart from the need to promote greater interaction with receptors. Furthermore, an informal and non-official rule was adopted by the editors. Hence, the suggestions chosen from the viewers' participation are put on the list of topics that might be on the news of the day, showing that the suggested stories are less important than those pre-defined as factual.

Nevertheless, journalists recognize that the new technology has modified the behavior of those who consume information and that the internet has mainly brought about mobility and the possibility of participation in journalistic content. With this perspective, new ways of communication have appeared but the technical means themselves are not enough to guarantee that the citizen becomes a prominent source and producer of news. However, the prior oversight of journalists as to what is broadcasted (or not) eliminates the possibility of more intense interaction, one which genuinely alters the context of media communication. 


\section{NOTES}

1 Without any type of restriction for obtaining the signal, that is, accessible through televisions without any kind of special treatment or additional equipment.

2 Television in Brazil has had general audience numbers in the last three decades of the 20th century, but is currently facing competition from new media, including codified television - cable or satellite -, and the internet, as well as the more traditional media, such as radio or the press.

3 We consider that TV Anhanguera viewer who sends news suggestions is part of the participative audience.

$4 \quad$ www.gl.com.br/goias

5 QVT - initials for "Quero ver na TV" used by the journalists in Anhanguera TV.

\section{| REFERENCES}

BENEVIDES, M. V. M. Cidadania ativa: referendo, plebiscito e iniciativa popular. 2 ed. São Paulo: Ática, 2003.

BRAGA, J. L.. Interação e recepção. IX ENCONTRO NACIONAL DA COMPÓS. Niterói, RJ, 2005. Anais. Compós, 2005. Available at: <http://www.compos. org.br/data/biblioteca_1399.pdf>. Accessed on: 10 nov. 2011.

CHARAUDEAU, Patrick. Discurso das mídias. São Paulo: Contexto, 2006.

CHAPARRO, Manuel Carlos. Iniciação a uma teoria das fontes: tipificação das fontes. $\mathrm{O}$ xis da questão (blog). Available at: <www.oxisdaquestao.com. br/integra_integra.asp?codigo=377>. Accessed on: 12 set. 2009.

CORTINA, Adela. Cidadãos do mundo - para uma teoria da cidadania. São Paulo: Loyola, 2005.

GENTILLI, V. Democracia de massas: jornalismo e cidadania - estudo sobre as sociedades contemporâneas e o direito dos cidadãos à informação. Porto Alegre: Edipucrs, 2005.

MARTINO, L. De qual comunicação estamos falando?. In A. Hohlfeldt; L. Martino; V. França (orgs.). Teorias da Comunicação. Conceitos Escolas e Tendências. Petrópolis: Vozes, 2001.

TEMER, A. C. R. P. Notícias e serviços nos telejornais da Rede Globo. Rio de Janeiro: Sotese, 2002.

TRAQUINA, N. Teorias do Jornalismo: a tribo jornalística - uma comunidade interpretativa transnacional. 2 ed. v. 2. Florianópolis: Insular, 2008.

THOMPSON, John B. A Mídia e a Modernidade: uma teoria social da mídia. Petrópolis: Vozes, 1995.

VIZEU, A. Decidindo o que é notícia: os bastidores do telejornalismo. Porto 
Alegre, Edipucrs, 2005.

VIZEU, A.; SIQUEIRA, F. C.. O telejornalismo: lugar de referência e a revolução das fontes. In: VIZEU, A.; PORCELLO, F.; COUTINHO, I. (Orgs). 60 anos de telejornalismo no Brasil: história, análise e crítica. Florianópolis: Insular, 2010. p.83-89.

Adriana Moraes is journalist. She got a master on Communication-media from Universidade Federal de Goiás. E-mail: at.moraes@terra.com.br

Ana Carolina Temer is journalist. She is doctor and a master degrees on Social Communication from Universidade Metodista de São Paulo. She is professor at the Post Graduation Program on Communication from Universidade Federal de Goiás. E-mail: anacarolina.temer@gmail.com Bernadete Coelho is journalist and master student at the Post Graduation Program on Communication from Universidade Federal de Goiás. E-mail: bernadetecoelhos@ gmail.com 